\title{
Reduced Locomotor Activity Correlates with Increased Severity of Arthritis in a Mouse Model of Antibody-Induced Arthritis
}

\author{
Narendiran Rajasekaran ${ }^{1}$, Ricky Tran ${ }^{1}$, Conrado Pascual ${ }^{2}$, Xinmin Xie $^{2}$, Elizabeth D. Mellins ${ }^{{ }^{*}}$ \\ ${ }^{1}$ Department of Pediatrics, Program in Immunology, Stanford University Medical Center, Stanford, USA; ${ }^{2}$ AfaSci Research Labora- \\ tory, Redwood City, USA. \\ Email: *mellins@stanford.edu
}

Received November $6^{\text {th }}, 2013$; revised December $6^{\text {th }}, 2013$; accepted December $14^{\text {th }}, 2013$

Copyright (C) 2014 Narendiran Rajasekaran et al. This is an open access article distributed under the Creative Commons Attribution License, which permits unrestricted use, distribution, and reproduction in any medium, provided the original work is properly cited. In accordance of the Creative Commons Attribution License all Copyrights (C) 2014 are reserved for SCIRP and the owner of the intellectual property Narendiran Rajasekaran et al. All Copyright (C) 2014 are guarded by law and by SCIRP as a guardian.

\section{ABSTRACT}

Introduction: Rheumatoid arthritis (RA) is a chronic autoimmune disease characterized by synovial hyperplasia and progressive cartilage and bone destruction that leads to a substantial loss of general functions and/or a decline in physical activities such as walking speed in humans. The $\mathrm{K} / \mathrm{BxN}$ serum transfer arthritis in mice shares many immunological and pathological features with human RA. Very few studies are available in mice that investigate the changes in physical activity in relation to arthritis development. In this study we investigate the effect of arthritis on the locomotor activity of mice during $\mathrm{K} / \mathrm{BxN}$ sera transfer arthritis. Methods: Arthritis was induced in Balb/c mice by injecting intraperitoneally with $200 \mu \mathrm{l} \mathrm{of} \mathrm{K/BxN} \mathrm{sera;} \mathrm{Balb/c} \mathrm{mice} \mathrm{injected} \mathrm{with} \mathrm{phos-}$ phate buffered saline (PBS) served as control. Progress of arthritis was estimated by daily measurements of joint thickness. Each mouse's locomotor activity (travel distance and travel time) was assessed every day for duration of 20 minute period using the SmartCage ${ }^{\mathrm{TM}}$ platform. Data were analyzed using the SmartCage ${ }^{\mathrm{TM}}$ analysis software (CageScore $\left.{ }^{\mathrm{TM}}\right)$. Results: Arthritic Balb/c mice showed a reduction in distance covered and travel speed when compared to arthritis-free, control Balb/c mice. Maximum decline in locomotor activity was observed during the peak period of the disease and correlated to the increase in joint thickness in the arthritic mice. Conclusion: This report demonstrates that measuring locomotor activity of mice during progression of $\mathrm{K} / \mathrm{BxN}$ serainduced arthritis using the SmartCage ${ }^{\mathrm{TM}}$ platform offers a quantitative method to assess physical activity in mice during arthritis.

\section{KEYWORDS}

K/BxN; Arthritis; Locomotion; Serum Transfer

\section{Introduction}

Rheumatoid arthritis (RA) is a chronic, inflammatory, autoimmune disease that primarily affects the synovial joints. It affects around $1 \%$ of the world population. The joints of RA patients develop synovial inflammation and undergo progressive damage of the musculoskeletal system that leads to impairment of physical function and quality of life [1-4]. Studies have revealed that RA patients exhibit an overall reduction in physical activity

\footnotetext{
"Corresponding author.
}

when compared to normal healthy patients [5-7]. If left untreated, RA can develop into a disabling condition that results in a loss of mobility. This reduction in activity often leads to subpar work performance that can lead to job loss and/or unsatisfactory economic productivity [8]. Research characterizing the physical activity in RA patients will help in the development of advanced interventions that will improve their quality of life [9].

Animal models of RA have been useful in understanding the pathogenic mechanisms and to developing novel therapeutics to treat RA [10]. However, few stu- 
dies have been done to measure locomotor activity in these animal models as a measure of disease progression [11-14]. One such model, the K/BxN mice-obtained by crossing the KRN mice with the NOD/Lt mice-develop spontaneous arthritis by 4 weeks of age. The $\mathrm{T}$ cells in the $\mathrm{K} / \mathrm{BxN}$ mice carry a transgenic $\mathrm{T}$ cell receptor (TCR) that recognizes a ubiquitous protein glucose-6-phosphate isomerase (GPI) in the context of the NOD MHC II IA ${ }^{\mathrm{g} 7}$. Upon activation these $T$ cells provide help to $B$ cells that generate autoantibodies against GPI [15]. Serum from the $\mathrm{K} / \mathrm{BxN}$ mice can cause arthritis when injected into a wide variety of mouse strains [15]. Passage of the antibodies into the joints initiates an immune complex mediated disease that requires neutrophils, macrophages, mast cells and Th17 cells for disease development [15-18]. Unlike the $\mathrm{K} / \mathrm{BxN}$ - or the collagen-induced arthritis mouse models that are strain dependent, the $\mathrm{K} / \mathrm{BxN}$ sera transfer arthritis can be induced in a variety of mouse strains and it is not dependent on breaking of $\mathrm{T}$ cell tolerance. These distinguishing features have made the $\mathrm{K} / \mathrm{BxN}$ sera-induced arthritis valuable in investigating factors contributing to inflammation, and bone and cartilage destruction during arthritis [15]. In these investigations, the disease progression in mice was primarily monitored by macroscopic evaluation of the clinical signs of arthritis (ankle thickness measurements and clinical score) and histological evaluation of the joints. Until now the effect of arthritis on the locomotor activity in these mice has not been investigated although a recent study investigated the locomotor activity in the related transgenic $\mathrm{K} / \mathrm{BxN}$ mice $[11,13]$. Here, we report a simple non-invasive quantitative method to study locomotor activity during $\mathrm{K} / \mathrm{BxN}$ sera transfer arthritis using the SmartCage ${ }^{\mathrm{TM}}$ platform. This new system is composed of infrared (IR) matrices for activity, position, and locomotion detection. All signals are transmitted via USB cable to a personal computer and data were analyzed automatically using the Windows-based program CageScore $^{\mathrm{TM}}$ [19]. This system provides a simple, versatile, and cost-effective platform for quantification of locomotor activity in mice during arthritis. We show here that mice exhibit reduced locomotor activity during $\mathrm{K} / \mathrm{BxN}$ sera-induced arthritis and discuss its significance in investigating the development of arthritis.

\section{Methods}

\subsection{Animals}

KRN mice with a transgenic TCR against GPI were kindly provided by Dr. Diane Mathis (Harvard Medical School, Boston, MA). NOD/Lt mice and Balb/c were obtained from Jackson laboratory. The arthritic $\mathrm{K} / \mathrm{BxN}$ mice were obtained by crossing KRN mice with NOD mice, as is standard [20]. All animals were bred, housed, and cared for in the Stanford Veterinary Service Center under the approval of the Administrative Panel for Laboratory Animal Care, protocol no. 15867.

\subsection{Serum Transfer Arthritis}

$\mathrm{K} / \mathrm{BxN}$ serum was collected from 8-week-old $\mathrm{K} / \mathrm{BxN}$ mice and pooled for each experiment. Arthritis was induced by intraperitoneal injection of $200 \mu \mathrm{L}$ of $\mathrm{K} / \mathrm{BxN}$ sera on day 0 . Thickness of the ankle joints of all the four limbs was measured with a micrometer (Mitutoyo) for 14 days. Joint thickness, the summed average of the thickness of all four limbs per mice, is expressed in millimeters.

\subsection{SmartCage ${ }^{\mathrm{TM}}$ System}

The SmartCage ${ }^{\mathrm{TM}}$ platform provides an inner space of $36.0 \times 23.0 \times 9.0 \mathrm{~cm}$ (length $\times$ width $\times$ height) for mice acts as a station for 'parking' a mouse cage (Figure 1). The infrared processor and instrument amplifier are assembled in the platform. Single USB cables are linked directly or via a hub to the host computer (32- or 64-bit Windows XP (Microsoft, Bellevue, WA, USA)) that provides power and operates up to 16 platforms simultaneously using a uniform graphical user interface and a data acquisition program termed CageCenter ${ }^{\mathrm{TM}}$, which comes with the Smart-Cage ${ }^{\mathrm{TM}}$ system. Data were analyzed automatically using the Windows-based program CageScore $^{\mathrm{TM}}$ (AfaSci, Inc. Burlingame, CA, USA). The locomotor activities, distance traveled and speed are calculated in a user defined time block. CageScore ${ }^{\mathrm{TM}}$ processes individual animal activity information and displays the data as the mean \pm SD in table and graphic formats.

\subsection{Statistical Analysis}

The groups were compared using Student's unpaired 2tailed $t$-test. GraphPad Prism software, version 6 was used for statistical analysis. For each test, $\mathrm{p}$ values $\leq 0.05$ were considered significant.

\section{Results}

\subsection{Development of Arthritis in the Balb/c Mice Injected with $\mathrm{K} / \mathrm{BxN}$ Sera}

Balb/c mice were injected intraperitonealy with $200 \mu$ of $\mathrm{K} / \mathrm{BxN}$ sera and the development of arthritis was monitored by measuring joint thickness daily as described in the Methods section. Balb/c mice injected with 1X PBS were treated as controls.

An increase in joint thickness was observed within 24 hrs in mice injected with $\mathrm{K} / \mathrm{BxN}$ sera $(9.13 \pm 0.14 \mathrm{~mm})$ 
whereas mice injected with PBS did not show any increase $(8.61 \pm 0.11 \mathrm{~mm})$. Subsequently, the joint thickness in the $\mathrm{K} / \mathrm{BxN}$ sera transferred mice increased progressively, reaching a maximum on day 6 (10.77 \pm 0.82 $\mathrm{mm}$ ) and gradually reduced to values comparable to that in the control mice by day $14(\mathrm{~K} / \mathrm{BxN}$ serum transfer$8.95 \pm 0.23 \mathrm{~mm}$; Control- $8.8 \pm 0.06 \mathrm{~mm}$; Figure 2). The increase in joint thickness in the arthritic mice was significant during all time points from day 1 to day 12 , when compared to the control mice $(\mathrm{p}<0.0005)$.

\subsection{Locomotor Activity in Mice during Progression of Arthritis}

Given the increase in joint thickness in mice injected with $\mathrm{K} / \mathrm{BxN}$ sera, we measured the changes in locomotor activity in these mice during the progression of arthritis. $\mathrm{K} /$ BxN sera-treated Balb/c mice and 1X PBS treated Balb/c

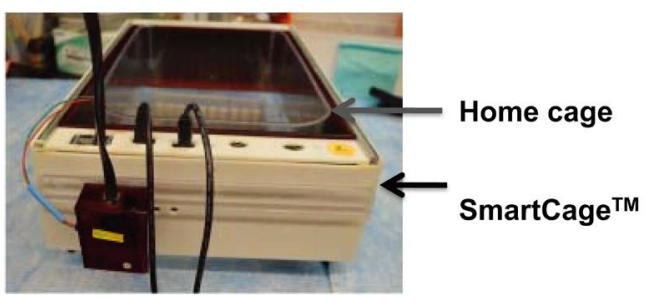

Figure 1. A SmartCage set up. An individual SmartCage with a normal mouse cage inside is shown here. The Infra red (IR) array is mounted inside the platform. The IR processor and a microcontrol unit are assembled at the front print circuit board. Signals from the SmartCage are transmitted by a single USB cable that links directly to the host PC.

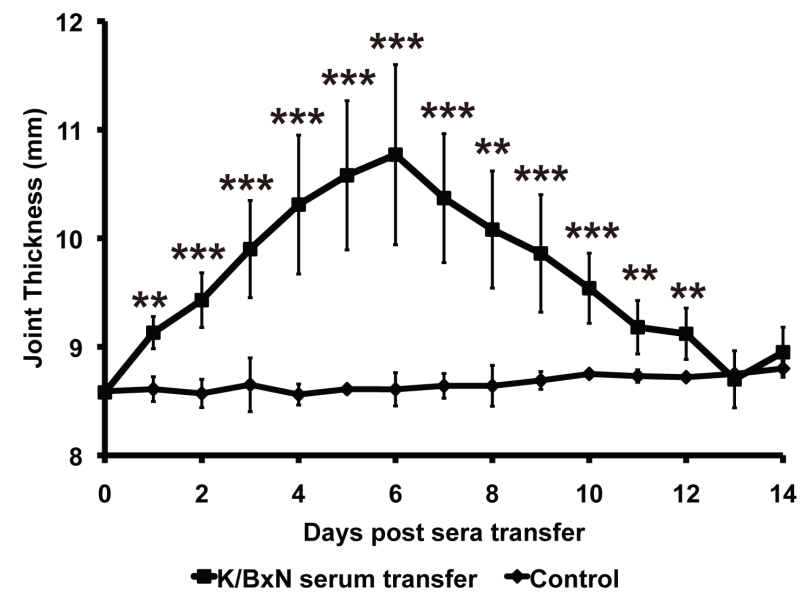

Figure 2. Characterization of $\mathbf{K} / \mathbf{B x N}$ sera induced arthritis by measuring joint thickness. Arthritis in the Balb/c mice injected with $\mathrm{K} / \mathrm{BxN}$ sera $(\mathrm{K} / \mathrm{BxN}$ serum transfer; $\mathrm{n}=5)$ was followed by measuring joint thickness every day. Balb/c mice (Control; $n=5$ ) injected with 1 XPBS were used as non-arthritic controls. Each point in the graph represents mean \pm SD, ${ }^{* *} \mathbf{p}<0.005,{ }^{* * *} \mathbf{p}<0.0005$. mice were each placed individually in a SmartCage (as explained in the Materials and Methods). Locomotor activity was recorded for 25 minutes using the SmartCage ${ }^{\mathrm{TM}}$ acquisition software (CageCenter ${ }^{\mathrm{TM}}$ ) and analyzed using the SmartCage ${ }^{\mathrm{TM}}$ analysis software (CageScore ${ }^{\mathrm{TM}}$ ). Because mice often require a few minutes to explore and accommodate to a new cage environment, the first $5 \mathrm{mi}-$ nutes of each SmartCage recording was not considered for analysis. The data acquired in the final 20 minutes of each recording session was used for analysis. In order to investigate the locomotor activity of mice during arthritis we considered two parameters of activity: Travel Distance and Travel Speed.

\subsection{Travel Distance}

On analyzing the distance covered by mice as a measure of locomotor activity, it was determined that in $\mathrm{K} / \mathrm{BxN}$ sera-injected mice, the distance traveled decreased with the progression of arthritis (Figure 3(a)). This reduction in travel distance by the arthritic mice when compared to the travel distance of the control mice was statistically significant on day 4 (K/BxN serum transfer-362 \pm 198 $\mathrm{cm}$; Control-1111.6 $\pm 401 \mathrm{~cm}, \mathrm{p}=0.01)$, day $5(\mathrm{~K} / \mathrm{BxN}$ serum transfer-369 $\pm 165 \mathrm{~cm}$; Control $-639 \pm 154 \mathrm{~cm}$, $\mathrm{p}=0.005)$ and day $6(\mathrm{~K} / \mathrm{BxN}$ serum transfer $-429 \pm 189$ $\mathrm{cm}$; Control-1052 $\pm 500 \mathrm{~cm}, \mathrm{p}=0.02)$ post-sera transfer (Figure 3(b)). Furthermore, when we plotted the distance traveled by individual mice at each time point against their corresponding joint thickness measurements, (Figure 3(c)) we found that mice showing larger joint thickness during arthritic progression traveled a considerably shorter distance when compared to mice with smaller joint thickness. Thus, there is a clear correlation between the distance traveled and the increase in joint thickness (Pearson $r=-0.5445$ ) during the progress of arthritis.

\subsection{Travel Speed}

The net amount of time taken for traveling by both $\mathrm{K} / \mathrm{BxN}$ serum injected arthritic mice and control mice was acquired by the SmartCage ${ }^{\mathrm{TM}}$ acquisition software and was used to calculate the travel speed (distance traveled/time spent traveling). The speed with which the $\mathrm{K} / \mathrm{BxN}$ serum injected arthritic mice traveled during the progression of arthritis was significantly low when compared to the control mice on day $4(\mathrm{~K} / \mathrm{BxN}$ serum transfer $-126.2 \pm 14 \mathrm{~cm} / \mathrm{min}$; Control $-170 \pm 8.19 \mathrm{~cm} / \mathrm{min}$, p $=0.0003)$, day $5(\mathrm{~K} / \mathrm{BxN}$ serum transfer-116.2 \pm 4.29 $\mathrm{cm} / \mathrm{min}$; Control-138 $\pm 16.5 \mathrm{~cm} / \mathrm{min}, \mathrm{p}=0.024)$ and day $6(\mathrm{~K} / \mathrm{BxN}$ serum transfer- $117 \pm 4.2 \mathrm{~cm} / \mathrm{min}$; Control-138 $\pm 16.5 \mathrm{~cm} / \mathrm{min}, \mathrm{p}=0.016$ ) (Figure 4(a)). On plotting the joint thickness values of the arthritic mice against their travel speed, we observed that similar to the 


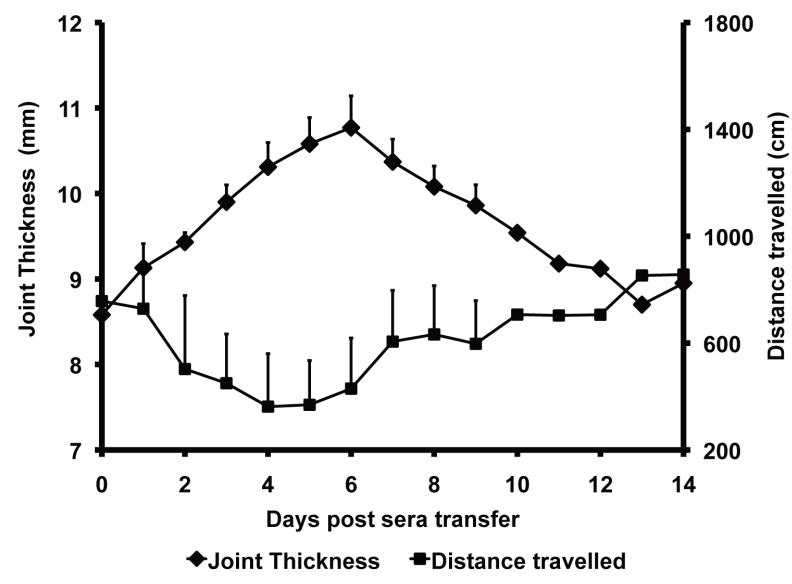

(a)

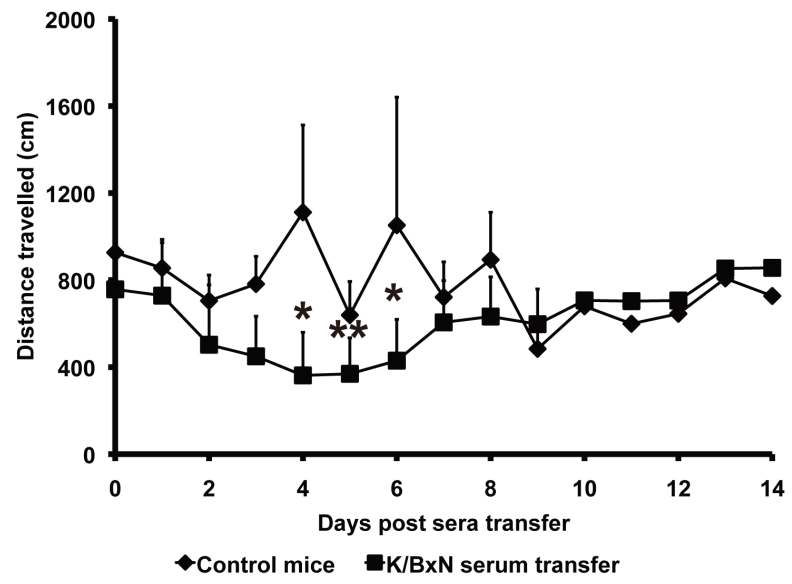

(b)

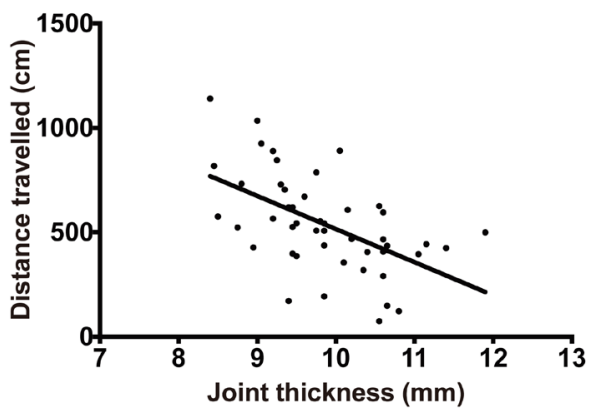

(c)

Figure 3. Distance traveled by mice declines with development of arthritis. Balb/c mice injected with $\mathrm{K} / \mathrm{BxN}$ sera were placed in the SmartCage and the distance traveled by the mice was recorded. (a) The distance traveled by Balb/c mice injected with $\mathrm{K} / \mathrm{BxN}$ sera is compared with the increase in joint thickness measured in parallel. Each point in the graph represents mean \pm $\mathrm{SD}, \mathrm{n}=5$. (b) The distance traveled by the Balb/c mice injected with $\mathrm{K} / \mathrm{BxN}$ sera $(\mathrm{K} / \mathrm{BxN}$ serum transfer) is compared to the distance traveled by the Balb/c mice that received 1 XPBS (Control). Each point in the graph represents mean \pm SD, $n=5$, ${ }^{*} p$ $<0.05,{ }^{* *} \mathrm{p}<0.005$. (c) The distance traveled by Balb/c mice injected with $\mathrm{K} / \mathrm{BxN}$ sera in correlation to the joint thickness, $\mathrm{n}=$ 60, Pearson $r=-0.5445$. Data are representative of two independent experiments.

travel distance results, the speed of travel decreased with increase in joint thickness (Figure 4(b)). Furthermore, there was a significant correlation between the decrease in speed and the increase in joint thickness of $\mathrm{K} / \mathrm{BxN}$ sera-injected arthritic mice (Figure 4(c)). Thus, the above data demonstrate that locomotor activity reduces with increasing joint thickness during $\mathrm{K} / \mathrm{BxN}$ sera-induced arthritis in Balb/c mice.

\section{Discussion}

The current study has examined the $\mathrm{K} / \mathrm{BxN}$ sera transfer model as a tool for studying locomotor activity in mice during arthritis. We have used the SmartCage ${ }^{\mathrm{TM}}$ system to record and analyze the locomotor activity of mice. We analyzed the distance traveled and speed of travel by the mice during the development of arthritis. Even though $\mathrm{K} / \mathrm{BxN}$ sera-injected mice showed an increase in joint swelling on day 1 post-sera transfer, they showed a significant decrease in the locomotor activity compared to the controls only from days 4 to 6 when joint swelling reached maximum levels. Our data demonstrate that a maximum decline in physical activity corresponds to the peak inflammation period. This reflects a similar correlation seen between clinical arthritis and locomotion observed in other rodent models [12,21]. Even though the decline in locomotion was significantly different from the control only at the peak period of the disease, we observed a strong inverse correlation between distance covered, travel speed, and joint thickness in the arthritic mice throughout the progression of the disease. This implies that locomotor activity is modulated by the phase of inflammation that affects the mice. Given these measureable physical activity parameters, the SmartCage ${ }^{\mathrm{TM}}$ platform can be a useful tool to determine the effect of inflammation and pain on physical activity in $\mathrm{K} / \mathrm{BxN}$ sera transfer arthritic mice.

Human RA patients also exhibit reduced walking speed compared to healthy patients [22-24], and this is 


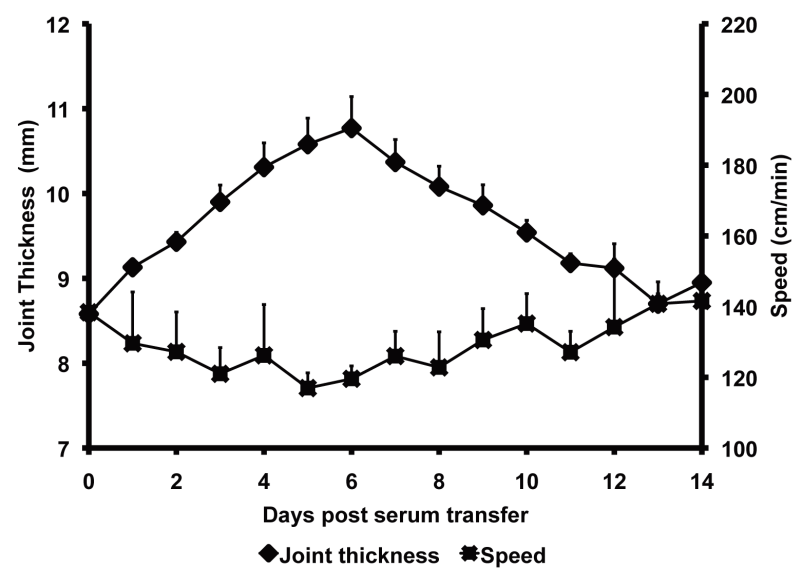

(a)

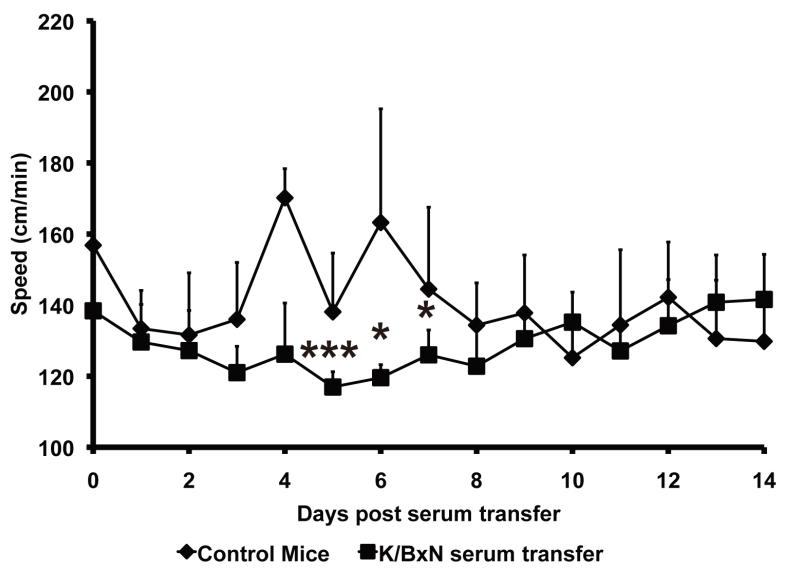

(b)

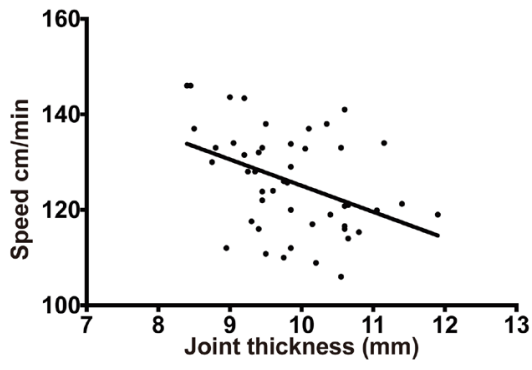

(b)

Figure 4. Speed of mice declines during progress of arthritis Balb/c mice injected with $\mathrm{K} / \mathrm{BxN}$ sera were placed in the SmartCage and time spent in travel was recorded. The distance traveled was then divided by the time spent in travel to give the travelling speed. (a) The travel speed of Balb/c mice after sera transfer is compared with the increase in joint thickness measured in parallel. Each point in the graph represents mean $\pm S D, n=5$. (b) The travel speed of the Balb/c mice injected with $\mathrm{K} / \mathrm{BxN}$ sera $(\mathrm{K} / \mathrm{BxN}$ serum transfer) is compared to the travel speed of the Balb/c mice that received 1 XPBS (Control). Each point in the graph represents mean $\pm \mathrm{SD}, \mathrm{n}=5,{ }^{*} \mathrm{p}<0.05,{ }^{* * *} \mathrm{p}<0.005$. (c) The travel speed of Balb/c mice injected with $\mathrm{K} / \mathrm{BxN}$ sera in correlation to the joint thickness, $n=60$, Pearson $r=-0.4131$. Data are representative of two independent experiments.

accompanied by active joint disease [23,25,26]. Inflammatory synovitis and dysfunction of the muscle-tendon junctions are postulated mechanisms leading to instability of the joints [27] and loss of foot function which results in a decline in locomotor functions. Another possible explanation for the decline in locomotor function in these arthritic mice is hyperalgesia that manifests at the peak of inflammation. Hyperalgesia in arthritis is caused by the pain-inducing cytokines produced by immune cells. Recently, IL-6 - a cytokine expressed during inflammation was found to be involved in the generation of pain in a model of antigen-induced arthritis [28]. Similarly IL- $1 \beta$ plays a central role in the generation of mechanical hyperaglesia in a pain model in mice $[29,30]$. A recent study investigated the mechanisms of pain in this model [11]. They conducted behavioral tests such as the thermal paw threshold and von Frey mechanical threshold tests to show that $\mathrm{K} / \mathrm{BxN}$ serum transfer arthritis induces tactile allodynia during the inflammatory phase. Decrease in physical activity is closely correlated with pain in RA patients, and is often caused and exacerbated by several inflammatory mediators (prostaglandin E2 and inflammatory cytokines) [5-7]. Decrease in activity is also correlated with a decrease in muscle strength and joint destruction in RA patients [8].

Diet plays an important role in the management of RA, and studies have suggested that polyunsaturated fatty acids and antioxidants can alleviate symptoms of the disease [31-34]. However, these studies in humans are hampered by the variability in the clinical course of the disease and in the self-prescribed diets of patients that prove difficult to monitor. These shortcomings in human studies can be overcome by studying the effect of the dietary modifications on clinical disease and locomotor function during arthritis in the $\mathrm{K} / \mathrm{BxN}$ serum transfer model with the SmartCage ${ }^{\mathrm{TM}}$ platform.

In the present study, we have demonstrated that mice exhibit reduced locomotor activity during $\mathrm{K} / \mathrm{BxN}$ serainduced arthritis. Importantly, we were able to correlate the progress of arthritis measured as an increase in joint 
thickness with the decline in locomotor activity measured using the SmartCage ${ }^{\mathrm{TM}}$ apparatus. Thus we have developed a platform to study the factors that are responsible for the decline in physical activity during joint inflammation in mice. This platform will aid in discovering novel therapeutic strategies to treat arthritis in humans.

\section{Disclosures}

$\mathrm{X} . \mathrm{X}$ is the founder and owner of AfaSci, Inc.

\section{Authors' Contributions}

NR designed and conducted experiments, analyzed results and wrote the manuscript; RT conducted experiments and analyzed results; CP provided intellectual input and wrote manuscript; XX provided intellectual input and the SmartCage ${ }^{\mathrm{TM}}$ apparatus; EDM contributed to the experimental design, data analysis and wrote the manuscript.

\section{Acknowledgements}

This work was supported by grants from Arthritis Foundation (to NR), J American College of Rheumatology Research and Education Foundation, and NIH AI075253 and DK079163 (to EDM).

\section{REFERENCES}

[1] R. C. Lawrence, C. G. Helmick, F. C. Arnett, R. A. Deyo, D. T. Felson, E. H. Giannini, S. P. Heyse, R. Hirsch, M. C. Hochberg, G. G. Hunder, et al., "Estimates of the Prevalence of Arthritis and Selected Musculoskeletal Disorders in the United States," Arthritis \& Rheumatism, Vol. 41, No. 5, 1998, pp. 778-799.

http://dx.doi.org/10.1002/1529-0131(199805)41:5<778:: AID-ART4>3.0.CO;2-V

[2] G. Plasqui, "The Role of Physical Activity in Rheumatoid Arthritis,” Physiology \& Behavior, Vol. 94, No. 2, 2008, pp. 270-275.

http://dx.doi.org/10.1016/j.physbeh.2007.12.012

[3] M. Tierney, A. Fraser and N. Kennedy, "Physical Activity in Rheumatoid Arthritis: A Systematic Review,” Journal of Physical Activity \& Health, Vol. 9, No. 7, 2012, pp. 1036-1048.

[4] C. L. Backman, "Employment and Work Disability in Rheumatoid Arthritis," Current Opinion in Rheumatology, Vol. 16, No. 2, 2004, pp. 148-152. http://dx.doi.org/10.1097/00002281-200403000-00014

[5] R. Roubenoff, J. Walsmith, N. Lundgren, L. Snydman, G. J. Dolnikowski and S. Roberts, "Low Physical Activity Reduces Total Energy Expenditure in Women with Rheumatoid Arthritis: Implications for Dietary Intake Recommendations," American Journal of Clinical Nutrition, Vol. 76, No. 4, 2002, pp. 774-779.

[6] L. Hagfors, K. Westerterp, L. Skoldstam and G. Johans- son, "Validity of Reported Energy Expenditure and Reported Intake of Energy, Protein, Sodium and Potassium in Rheumatoid Arthritis Patients in a Dietary Intervention Study," European Journal of Clinical Nutrition, Vol. 59, 2005, pp. 238-245. http://dx.doi.org/10.1038/sj.ejcn.1602064

[7] S. R. Piva, G. J. Almeida and M. C. Wasko, “Association of Physical Function and Physical Activity in Women with Rheumatoid Arthritis," Arthritis Care \& Research (Hoboken), Vol. 62, No. 8, 2010, pp. 1144-1151. http://dx.doi.org/10.1002/acr.20177

[8] X. Li, M. A. Gignac and A. H. Anis, "The Indirect Costs of Arthritis Resulting from Unemployment, Reduced Performance, and Occupational Changes While at Work," Medical Care, Vol. 44, No. 4, 2006, pp. 304-310. http://dx.doi.org/10.1097/01.mlr.0000204257.25875.04

[9] N. Kennedy, F. Keogan, M. Fitzpatrick, G. Cussen and L. Wallace, "Characteristics of Patients with Rheumatoid Arthritis Presenting for Physiotherapy Management: A Multicentre Study,” Musculoskeletal Care, Vol. 5, No. 1, 2007, pp. 20-35. http://dx.doi.org/10.1002/msc.93

[10] D. L. Asquith, A. M. Miller, I. B. McInnes and F. Y. Liew, "Animal Models of Rheumatoid Arthritis," European Journal of Immunology, Vol. 39, No. 8, 2009, pp. 2040-2044. http://dx.doi.org/10.1002/eji.200939578

[11] C. A. Christianson, M. Corr, G. S. Firestein, A. Mobargha, T. L. Yaksh and C. I. Svensson, "Characterization of the Acute and Persistent Pain State Present in K/BxN Serum Transfer Arthritis,” Pain, Vol. 151, No. 2, 2010, pp. 394403. http://dx.doi.org/10.1016/j.pain.2010.07.030

[12] A. Hartog, J. Hulsman and J. Garssen, "Locomotion and Muscle Mass Measures in a Murine Model of CollagenInduced Arthritis,” BMC Musculoskeletal Disorders, Vol. 10, No. 1, 2009, p. 59. http://dx.doi.org/10.1186/1471-2474-10-59

[13] D. Frommholz and H. Illges, "Maximal Locomotor Depression Follows Maximal Ankle Swelling during the Progression of Arthritis in K/BxN Mice," Rheumatology International, Vol. 32, No. 12, 2012, pp. 3999-4003. http://dx.doi.org/10.1007/s00296-011-2337-5

[14] J. Vincelette, Y. Xu, L. N. Zhang, C. J. Schaefer, R. Vergona, M. E. Sullivan, T. G. Hampton and Y. X. Wang, "Gait Analysis in a Murine Model of Collagen-Induced Arthritis,” Arthritis Research and Therapy, Vol. 9, No. 6, 2007, p. R123. http://dx.doi.org/10.1186/ar2331

[15] L. Mandik-Nayak and P. M. Allen, "Initiation of an Autoimmune Response: Insights from a Transgenic Model of Rheumatoid Arthritis,” Immunologic Research, Vol. 32, No. 1-3, 2005, pp. 5-13. http://dx.doi.org/10.1385/IR:32:1-3:005

[16] B. T. Wipke, Z. Wang, W. Nagengast, D. E. Reichert and P. M. Allen, "Staging the Initiation of Autoantibody-Induced Arthritis: A Critical Role for Immune Complexes,” Journal of Immunology, Vol. 172, No. 12, 2004, pp. 7694-7702.

[17] B. T. Wipke, Z. Wang, J. Kim, T. J. McCarthy and P. M. Allen, "Dynamic Visualization of a Joint-Specific Autoimmune Response through Positron Emission Tomogra- 
phy,” Nature Immunology, Vol. 3, No. 4, 2002, pp. 366372. http://dx.doi.org/10.1038/ni775

[18] H. Ji, A. Pettit, K. Ohmura, A. Ortiz-Lopez, V. Duchatelle, C. Degott, E. Gravallese, D. Mathis and C. Benoist, "Critical Roles for Interleukin 1 and Tumor Necrosis Factor Alpha in Antibody-Induced Arthritis,” Journal of EXperimental Medicine, Vol. 196, No. 1, 2002, pp. 77-85. http://dx.doi.org/10.1084/jem.20020439

[19] T. V. Khroyan, J. Zhang, L. Yang, B. Zou, J. Xie, C. Pascual, A. Malik, N. T. Zaveri, J. Vazquez, W. Polgar, et al., "Rodent Motor and Neuropsychological Behaviour Measured in Home Cages Using the Integrated Modular Platform SmartCage," Clinical and Experimental Pharmacology and Physiology, Vol. 39, No. 7, 2012, pp. 614622. http://dx.doi.org/10.1111/j.1440-1681.2012.05719.x

[20] V. Kouskoff, A. S. Korganow, V. Duchatelle, C. Degott, C. Benoist and D. Mathis, "Organ-Specific Disease Provoked by Systemic Autoimmunity,” Cell, Vol. 87, No. 5, 1996, pp. 811-822. http://dx.doi.org/10.1016/S0092-8674(00)81989-3

[21] S. U. Simjee, H. Jawed, J. Quadri and S. A. Saeed, "Quantitative Gait Analysis as a Method to Assess Mechanical Hyperalgesia Modulated by Disease-Modifying Antirheumatoid Drugs in the Adjuvant-Induced Arthritic Rat,” Arthritis Research \& Therapy, Vol. 9, No. 5, 2007, p. R91. http://dx.doi.org/10.1186/ar2290

[22] R. Dubbeldam, A. V. Nene, J. H. Buurke, C. G. Groothuis-Oudshoorn, H. Baan, K. W. Drossaers-Bakker, M. A. van de Laar and H. Hermens, "Foot and Ankle Joint Kinematics in Rheumatoid Arthritis Cannot Only Be Explained by Alteration in Walking Speed," Gait Posture, Vol. 33, No. 3, 2011, pp. 390-395. http://dx.doi.org/10.1016/j.gaitpost.2010.12.010

[23] D. E. Turner, P. S. Helliwell, P. Emery and J. Woodburn, "The Impact of Rheumatoid Arthritis on Foot Function in the Early Stages of Disease: A Clinical Case Series," BMC Musculoskeletal Disorders, Vol. 7, No. 1, 2006, p. 102. http://dx.doi.org/10.1186/1471-2474-7-102

[24] M. van der Leeden, M. Steultjens, J. H. Dekker, A. P. Prins and J. Dekker, "The Relationship of Disease Duration to Foot Function, Pain and Disability in Rheumatoid Arthritis Patients with Foot Complaints," Clinical and Experimental Rheumatology, Vol. 25, No. 2, 2007, pp. 275-280.

[25] M. Yamada, T. Aoyama, S. Mori, S. Nishiguchi, K. Okamoto, T. Ito, S. Muto, T. Ishihara, H. Yoshitomi and H. Ito, "Objective Assessment of Abnormal Gait in Pa- tients with Rheumatoid Arthritis Using a Smartphone," Rheumatology International, Vol. 32, No. 12, 2012, pp. 3869-3874. http://dx.doi.org/10.1007/s00296-011-2283-2

[26] N. Miyamoto, M. Senda, M. Hamada, Y. Katayama, A. Kinosita, K. Uchida and H. Inoue, "Talonavicular Joint Abnormalities and Walking Ability of Patients with Rheumatoid Arthritis,” Acta Medica Okayama, Vol. 58, No. 2, 2004, pp. 85-90.

[27] E. T. Jernberg, P. Simkin, M. Kravette, P. Lowe and G. Gardner, "The Posterior Tibial Tendon and the Tarsal Sinus in Rheumatoid Flat Foot: Magnetic Resonance Imaging of 40 Feet,” Journal of Rheumatology, Vol. 26, No. 2, 1999, pp. 289-293.

[28] C. I. Svensson, “Interleukin-6: A Local Pain Trigger?” Arthritis Research and Therapy, Vol. 12, No. 5, 2010, p. 145. http://dx.doi.org/10.1186/ar3138

[29] S. H. Ferreira, B. B. Lorenzetti, A. F. Bristow and S. Poole, "Interleukin-1 Beta as a Potent Hyperalgesic Agent Antagonized by a Tripeptide Analogue,” Nature, Vol. 334, No. 6184, 1988, pp. 698-700. http://dx.doi.org/10.1038/334698a0

[30] C. Sommer, S. Petrausch, T. Lindenlaub and K. V. Toyka, "Neutralizing Antibodies to Interleukin 1-Receptor Reduce Pain Associated Behavior in Mice with Experimental Neuropathy," Neuroscience Letters, Vol. 270, No. 1, 1999, pp. 25-28. http://dx.doi.org/10.1016/S0304-3940(99)00450-4

[31] S. Y. Al-Okbi, "Nutraceuticals of Anti-Inflammatory Activity as Complementary Therapy for Rheumatoid Arthritis,” Toxicology and Industrial Health, 2012. http://dx.doi.org/10.1177/0748233712462468

[32] L. G. Darlington and N. W. Ramsey, "Review of Dietary Therapy for Rheumatoid Arthritis," Comprehensive Therapy, Vol. 20, 1994, pp. 490-494.

[33] L. G. Darlington and T. W. Stone, "Antioxidants and Fatty Acids in the Amelioration of Rheumatoid Arthritis and Related Disorders,” British Journal of Nutrition, Vol. 85, No. 3, 2001, pp. 251-269. http://dx.doi.org/10.1079/BJN2000239

[34] E. A. Miles and P. C. Calder, "Influence of Marine n-3 Polyunsaturated Fatty Acids on Immune Function and a Systematic Review of Their Effects on Clinical Outcomes in Rheumatoid Arthritis,” British Journal of Nutrition, Vol. 107, Suppl. 2, 2012, pp. S171-184. http://dx.doi.org/10.1017/S0007114512001560

\section{Abbreviations}

RA: Rheumatoid arthritis;

PBS: Phosphate buffered saline;

GPI: Glucose-6-phosphate isomerase. 